\title{
Retardation of senescence by low temperature and benzyladenine in intact primary leaves of soybean
}

\author{
Ching Huei Kao
}

Department of Agronomy, National Taiwan University, Taipei, Taiwan, Republic of China

(Received January 14, 1980)

\begin{abstract}
Effects of temperature and benzyladenine (BA) on the senescence of intact primary leaves of soybean were investigated. Compared with high temperature $\left(30^{\circ} \mathrm{C}\right.$ for day and $25^{\circ} \mathrm{C}$ for night), low temperature $\left(15^{\circ} \mathrm{C}\right.$ for day and $13^{\circ} \mathrm{C}$ for night) significantly retarded senescence of intact primary leaves. Repeated daily treatment of the primary leaves with BA ( $200 \mathrm{mg} / \mathrm{liter}$ ) beginning 15 days after growth at high temperature resulted in retardation of the senescence process. The lower activity of cytokinins in the primary leaves of seedlings grown under high temperature may be responsible for rapid senescence.
\end{abstract}

Key words: Benzyladenine - Cytokinins - Leaf senescence - Primary leaves Soybean - Temperature.

Cytokinins retard senescence in the detached leaves of many herbaceous plants (10). Unpublished data from this laboratory shows that, of seven cytokinins tested, BA, a synthetic cytokinin, was the most active for retarding the senescence of soybean leaf discs. The work of Kulaeva (9), Kende and Sitton (8), Wareing and Seth (2I), Hsia and $\mathrm{Kao}(5)$ and $\mathrm{Kao}(6)$ indicates that cytokinin-like substances produced by roots may regulate the senescence of leaves in intact plants. However, little or no effect on leaf senescence by cytokinins has been observed in intact plants $(9,17,19$ 21). Engelbrecht (2) reported that kinetin delayed leaf senescence in tobacco plants grown under low light. However, Fletcher (3) and Naito et al. (18) reported retardation of leaf senescence by BA in intact bean plants grown in strong light.

Very little information is avaialble about the effect of temperature on leaf senescence in intact plants. In a recent work (7), we found in a comparison with high temperature $\left(30^{\circ} \mathrm{C}\right.$ for day and $25^{\circ} \mathrm{C}$ for night), that low temperature $\left(20^{\circ} \mathrm{C}\right.$ for day and $15^{\circ} \mathrm{C}$ for night) at the pod-fill stage significantly retarded leaf senescence of podded, soybean plants. We here report the dinstinct retardation of senescence in intact primary leaves of soybean by low temperature and BA.

\section{Materials and methods}

Soybean (Glycine max Merr. cv. Shih-shih) plants were grown in a greenhouse in pots $\left(0.05 \mathrm{~m}^{2}\right)$ containing sandy loam. Natural light was provided and the temperature was controlled at $30^{\circ} \mathrm{C}$ during the day and $25^{\circ} \mathrm{C}$ at night. Seedlings

Abbreviation: BA, benzyladenine. 
were treated with high and low temperatures 15 days after planting. High temperature was maintained at $30^{\circ} \mathrm{C}$ during the day and $25^{\circ} \mathrm{C}$ at night, whereas the low temperature was $15^{\circ} \mathrm{C}$ during the day and $13^{\circ} \mathrm{C}$ at night. For BA treatment, seedlings were grown under high temperature. Primary leaves of 15-day-old seedlings were treated with $\mathrm{BA}(200 \mathrm{mg} / \mathrm{liter})$ at daily intervals by dipping them in BA solution containing $0.1 \%$ Tween 80 for a few seconds. In the water control, primary leaves were dipped in $0.1 \%$ Tween 80 . The primary leaves were harvested at the desired point after treatment; the leaf discs, $9 \mathrm{~mm}$ in diameter, were punched out with a cork borer and randomized.

The chlorophyll and $a$-amino nitrogen of groups of 10 leaf discs then were extracted with $80 \%$ ethanol at $30^{\circ} \mathrm{C}$ in darkness for $24 \mathrm{hr}$, after which the solution was brought to $10 \mathrm{ml}$ and its absorbance at $665 \mathrm{~nm}$ was read for the chlorophyll content. A sample $(0.2 \mathrm{ml})$ was used to determine the $a$-amino nitrogen by the Moore and Stein method (14). The extracted leaf discs then were treated with $2 \mathrm{ml}$ of $1 \mathrm{~N}$ $\mathrm{NaOH}$ at $90^{\circ} \mathrm{C}$ for $15 \mathrm{~min}$. After cooling the discs to room temperature, the $\mathrm{NaOH}$ solution was diluted to $0.5 \mathrm{~N}$ and samples were assayed for protein by Miller's (13) modification of the method of Lowry et al. (12).

\section{Results and discussion}

Fig. 1 shows the effect of temperature on the chlorophyll, protein and $a$-amino nitrogen contents of the primary leaves of soybean seedlings. Clearly, the levels of chlorophyll, protein and $a$-amino nitrogen declined more slowly in leaves treated with low temperature than in those treated with high temperature. Conventionally, changes in the levels of chlorophyll, or protein, or both are used as an index of senescence in detached and intact leaves. Judging by chlorophyll and protein levels, we deduced that low temperature significantly retards senescence of intact primary leaves when compared with high temperature treatment (Fig. 1). Low temperature also retarded leaf senescence of podded soybean plants (7). When soybean leaf discs were induced to senesce in darkness, the $a$-amino nitrogen level increased for six days then decreased rapidly (4). The low level of $a$-amino nitrogen in the primary leaves of seedlings treated with high temperature is not likely to be associated with the dilution effect caused by enlargement of the primary leaves because at the time of the temperature treatments these leaves were fully expanded. Probably the low level of $a$-amino nitrogen is due to the strong mobilizing force of the aerial portions above the primary leaves. This supposition is supported by the fact that the aerial portions above primary leaves grew more vigorously under high temperature than under low temperature.

Kulaeva (9) demonstrated that roots formed on leaf cuttings preserved these leaves, at least partly, through their supply of kinetin-like substances to the leaves. This and other subsequent studies $(5,6,8,21)$ suggested that root cytokinins are major factors in controlling leaf senescence. The ability of some parts of plants to mobilize substances from other parts has been known for years. Mothes (15) suggested that the chief mobilizing center in the plant competes with other parts for organic nutrients which are synthesized principally in roots. Hsia and Kao (5) reported that the aerial portions above the primary leaves of the soybean play the role of a mobilizing center. Davey and Van Staden (1) studied the distribution of 


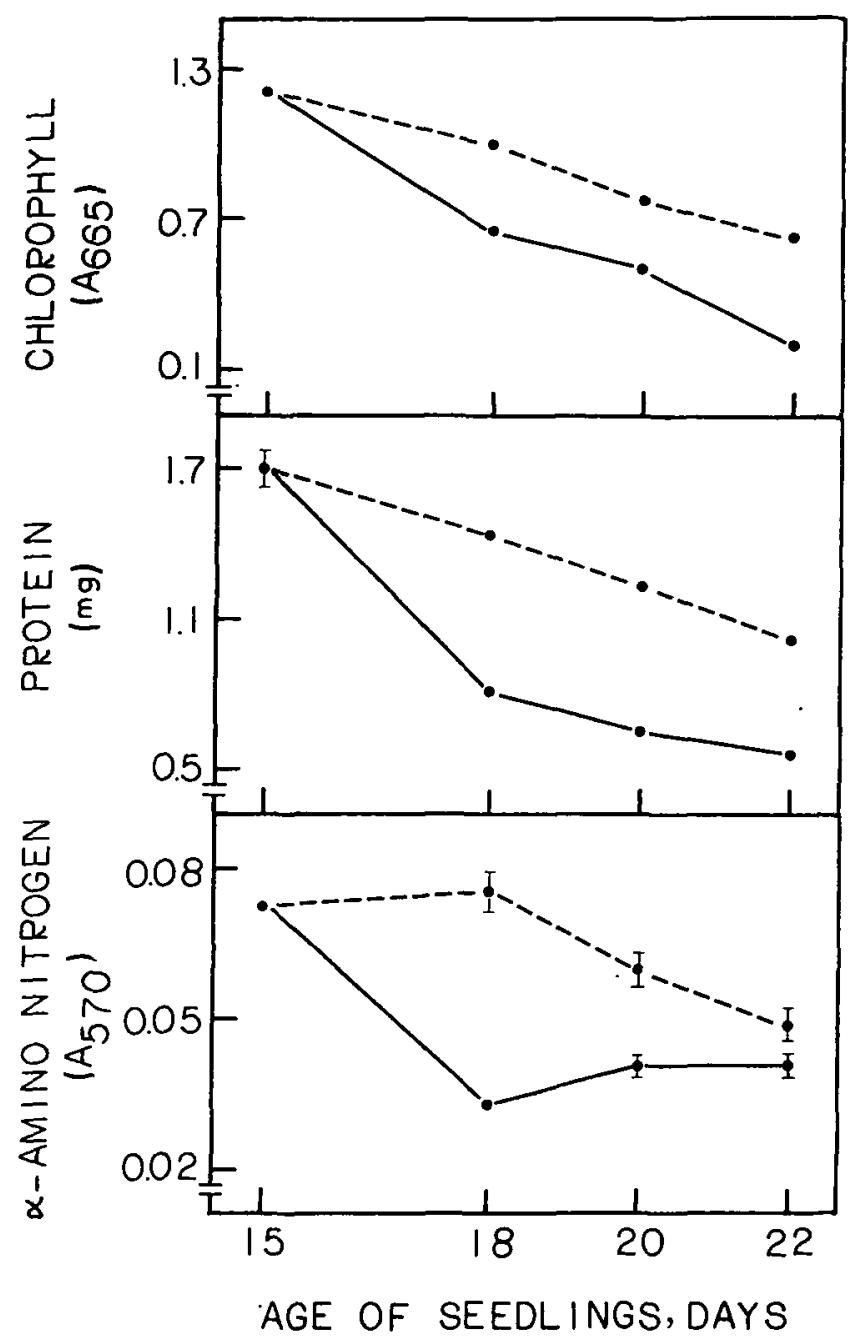

Fig. 1. Temperature effects on changes in chlorophyll, protein and a-amino nitrogen contents per 10 discs. Straight lines indicate high temperature, broken lines low temperature. The experiment was conducted in late August, 1979.

cytokinin activity in white lupin and concluded that cytokinins produced by the roots accumulate in the fully expanded, mature leaves, but are utilized in the rapidly growing apical region and in young expanding leaves. The aerial portions above the primary leaves grew more vigorously under high temperature; thus, their mobilizing ability to attract root cytokinins is greater than aerial portions under low temperature. Thus, endogenous cytokinins are presumably lower in the primary leaves of seedlings grown under high temperature than in those grown under low temperature. If the lower activity of cytokinins in primary leaves grown under high temperature is responsible for rapid senescence, then an exogenous supply of BA to the primary leaves would retard this senescence. This is indeed the case. Repeated 


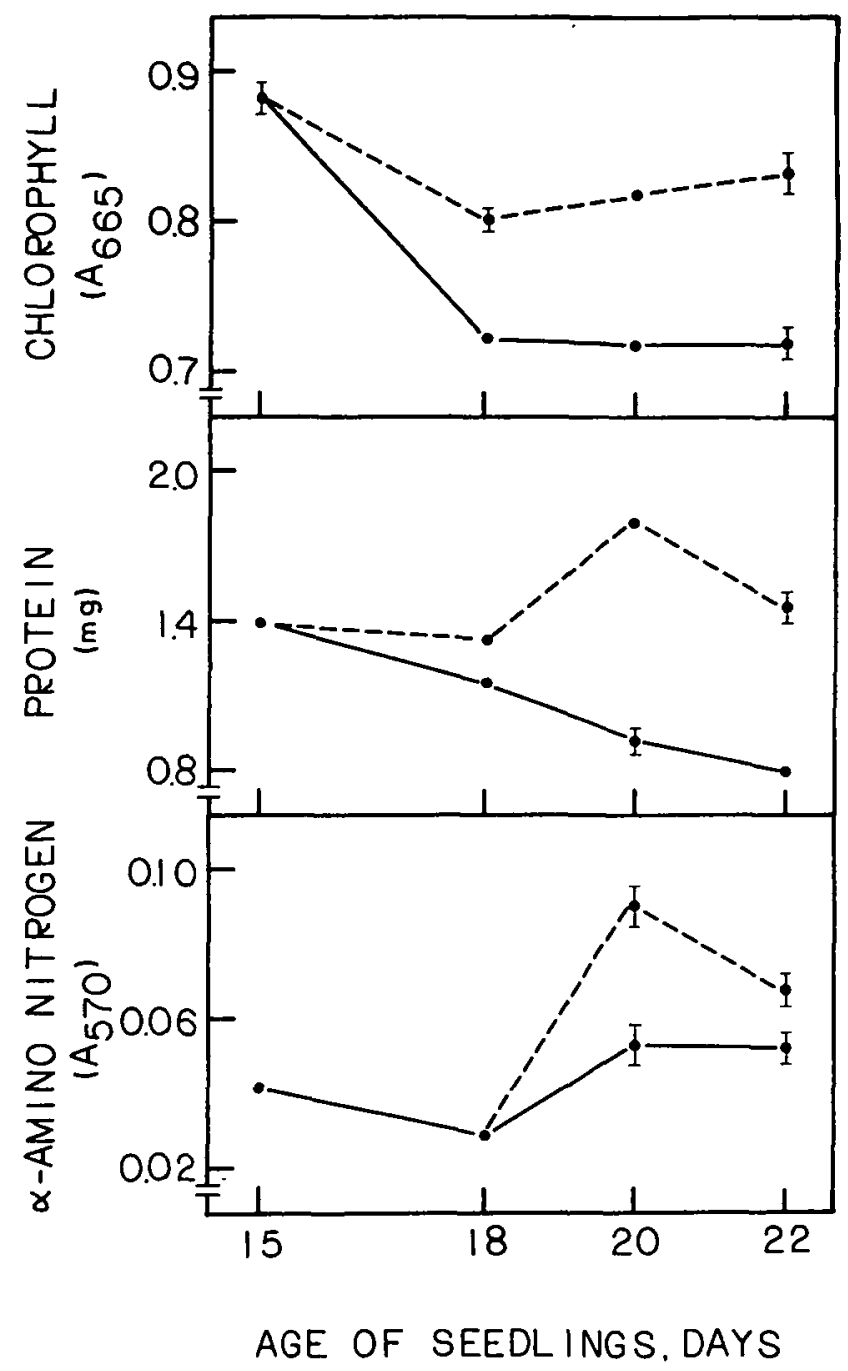

Fig. 2. BA effects on changes in chlorophyll, protein and a-amino nitrogen contents per 10 dises. Straight lines indicate water control, broken lines BA treatment. All seedlings were grown under high temperature. The experiment was conducted in late October, 1979.

daily treatment of primary leaves with BA beginning 15 days after planting resulted in high chlorophyll, protein and $a$-amino nitrogen contents (Fig. 2).

Senescence is a physiological process which could be affected by growth temperatures. Temperatures lower than $25^{\circ} \mathrm{C}$ have been reported to retard the senescence of soybean leaf discs (4). Thus, the senescence-retarding effect of low temperature might be explained on the basis that low temperature decreases the metabolism of the primary leaves.

In 1964, Engelbrecht (2) found that kinetin retarded leaf senescence in tobacco plants grown under low light. Since then, many attempts to establish cytokinin 
effects in intact plants have been made, but these have proved unsuccessful. However, Fletcher (3) and Naito et al. (18) found that an exogenous application of BA did retard the leaf senescence of intact bean plants grown under strong light. To our knowledge this is the first report of the effect of BA in retarding the senescence of intact primary leaves of the soybean. The increase in $\alpha$-amino nitrogen in intact leaves treated with BA is presumably due to cytokinins' attraction for nitrogenous compounds from other parts of the plant and to the retention of the $\alpha$-amino nitrogen formed in the leaves (16).

Based on the evidence presented in this paper and results of previous work $(5,7)$, the leaf senescence of soybean plants at different growth stages may be caused by different mechanisms. In soybean seedlings, leaf senescence is caused by competition among leaves for substances, possibly cytokinins, of root origin, whereas in podded soybean plants, it is triggered by a senescence hormone, possibly abscisic acid $(11)$, in developing pods or seeds.

The financial support of the JCRR of the Republic of China is gratefully acknowledged. Misses I. F. Su and S. M. Yu are thanked for their assistance.

\section{References}

(1) Davey, J. E. and J. Van Staden: Cytokinin activity in Lupinus albus I. Distribution in vegetative and flowering plants. Physiol. Plant. 43: 77-81 (1978).

(2) Engelbrecht, L.: Über Kinetinwirkungen bei intakten Blättern von Nicotiana rustica. Flora 154: 57-69 (1964).

(3) Fletcher, R. A.: Retardation of leaf senescence by benzyladenine in intact bean plants. Plante 89: 1-8 (1969).

(4) Hsia, C. P. and C. H. Kao: Some aspects of soybean leaf senescence. Mem. Coll. Agric. Natl. Taiwan Univ. 17(2): 68-77 (1977).

(5) Hsia, C. P. and C. H. Kao: The importance of roots in regulating the senescence of soybean primary leaves. Physiol. Plant. 43: 385-389 (1978).

(6) Kao, C. H.: Senescence of rice leaves IIJ. The interorgan control of leaf senescence of rice seedlings. Proc. Natl. Sci. Counc. ROC 3: 199-204 (1979).

(7) Kao, C. H.: Retardation of leaf senescence by low temperature and pod removal. Ann. Bot. (1980) (in press).

( 8 ) Kende, H. and D. Sitton: The physiological significance of kinetin and gibberellin-like root hormones. Ann. N.Y. Acad. Sci. 144: 235-243 (1967).

(9) Kulaeva, O. N.: The effect of roots on leaf metabolism in relation to the action of kinetin on leaves. Soviet Plant Physiol. 9: 182-189 (1962).

(10) Letham, D. S.: Chemistry and physiology of kinetin like compounds. Ann. Rev. Plant Physiol. 18: 349-364 (1967).

(11) Lindoo, S. J. and L. D. Noodén: Correlation of cytokinins and abscisic acid with monocarpic senescence in soybeans. Plant \& Cell Physiol. 19: 997-1006 (1978).

(12) Lowry, O. H., N. J. Rosebrough, A. L. Farr and R. J. Randall: Protein measurement with the Folin phenol reagent. J. Biol. Chem. 193: 265-275 (1951).

(13) Miller, G. L.: Protein determination for large numbers of samples. Anal. Chem. 31 : 964 (1959).

(14) Moore, S. and W. W. Stein: Photometric ninhydrin method for use in the chromatography of amino acids. J. Biol. Chem. 176: 367-388 (1948).

(15) Mothes, K.: Über das Altern der Blätter und die Möglichkeit iher Wiederverjüngung. Naturwissenschaften 47: 337-350 (1960). 
(16) Mothes, K. and L. Engelbrecht: Kinetin-induced directed transport of substances in excised leaves in the dark. Phytochem. 1: 58-62 (1961).

(17) Muller, K. and A. C. Leopold: Correlative ageing and transprt of $\mathrm{P}^{32}$ in corn leaves under the influence of kinetin. Planta 68: 167-185 (1966).

(18) Naito, K., H. Tsuji and I. Hatakeyama: Effect of benzyladenine on DNA, RNA, protein, and chlorophyll contents in intact bean leaves: Differential responses to benzyladenine according to leaf age. Physiol. Plant. 43: 367-371 (1978).

(19) Simon, E. W.: Types of leaf senescence. In Aspects of the Biology of Ageing. Edited by H. W. Woolhouse. p. 215-230. Cambridge Univ. Press, 1967.

(20) Srivastava, B. I. S. and R. K. Atkin: Effect of second leaf removal or kinetin treatment on the nucleic acid metabolism of senescing first seedling leaf of barley. Biochem. J. 107: 361-366 (1968).

(21) Wareing, P.F. and A.K. Seth: Ageing and senescence in the whole plant. In Aspects of the Biology of Ageing. Edited by H. W. Woolhouse. p. 543-558. Cambridge Univ. Press, 1967. 